\title{
Bir Hospital of Yore and Now
}

\section{Dixit $\mathrm{H}$}

Hemang Dixit, Professor and Head of Department, Medical Education, Kathmandu Medical College Teaching Hospital, Kathmandu, Nepal.

\section{ABSTRACT}

The setting up of the Bir Hospital about 125 years ago and its development over the years as a service and teaching institute is described.

\section{INTRODUCTION}

ome historians have stated the Bir Hospital was built $\checkmark$ because Bir Shumsher, desiring to be decorated by the British started doing some social service for the welfare of the public. Possibly because of this, he was made a Knight Commander of the Star of India in 1882. Subsequently he became a Knight Grand Commander in $1887^{1}$. It is likely that Bir Shumsher, realising that the small hospital established within the British Residency at Lainchaur would not be able to cope with the demand of modern Western medicine, decided to open a hospital, not only in the capital in 1889 (1947 BS) but to follow it up with another at Gahwa, renamed 'Birgunj' on the Indo-Nepal border in the Terai, the following year. It was therefore as a result of this step that the trend of opening hospitals in different parts of the country and naming it after the reigning monarch and the prime minister came into vogue.

The original Prithvi-Bir Hospital was one with only 30 beds and was initially located at the North Western corner of the Ranipokhari at the Rastriya Naachghar (National Theatre) site. The first document regarding this institution is the one from the Nijamati Kitab Khana dated $15^{\text {th }}$ Asar, 1947 BS, including the provision to pay a certain Indian Dr. Ganguly ${ }^{2}$. The hospital was later shifted in to its present site at the South Western corner of Ranipokhari, or the water tank in the centre of the town. The building of the hospital also reflected what Jung Bahadur had seen of Victorian architecture in England,

Address for correspondence

\section{Dr. Hemang Dixit}

Professor, Head of Department

Department of Medical Education, Kathmandu Medical College

Teaching Hospital

Kathmandu, Nepal

E-mail: h2dixit@gmail.com namely the white massive columnar structures. Other health institutions to be named Prithvi Bir Hospitals were set up at Birgunj, Jaleshwar, Hanumanagar (Rajbiraj), Nepalgunj and Taulihawa ${ }^{3}$. The leprosarium at Khokana was built during this time. It is also likely that a certain Dr. Raj Krishna Mukherjee came to Kathmandu during the later years of Bir Shumsher's premiership, a period that was marked by improvements in education, sanitation, hospitals and the building of bridges ${ }^{4}$.

This same Dr. RK Mukherjee was first appointed as Inspector of Hospitals and later during the course of 114 days Dev Shumsher's premiership was appointed a lecturer at the Nepal Medical College. A news item in the Gorkhapatra of $11^{\text {th }}$ Jestha 1985 reported that Dr. Mukherjee had publicly dissected a dead body and shown the various internal organs to the prime minister Dev Shumsher. Thus the history of the hospital in the service and education sectors goes quite a long time back. In course of time however the institution came to be known as Bir Hospital.

It was during the time of Chandra Shumsher's premiership that a Chandra Sale Dispensary was set up at Bir Hospital in 1917. Addition was also made to the Bir Female Hospital which was on a site on two sides of a road that went from the Western edge of the Tundikhel towards the Mahaboudha stupa. Two new sections of pathology/ bacteriology and an X-ray department were also started. Initially almost all the medical personnel were Bengali doctors but in course of time Nepali doctors gradually came to work there. Dr. Ganesh Lal Maskey was the first Licentiate of Medical Faculty (LMF) to be followed by Dr. Indra Man Baidya and Dr. Yagya Man Baidya. Dr. Siddhimani Dixit who graduated with MB (Cal) in April 1921 was probably the first person to qualify with a degree in modern medicine. 

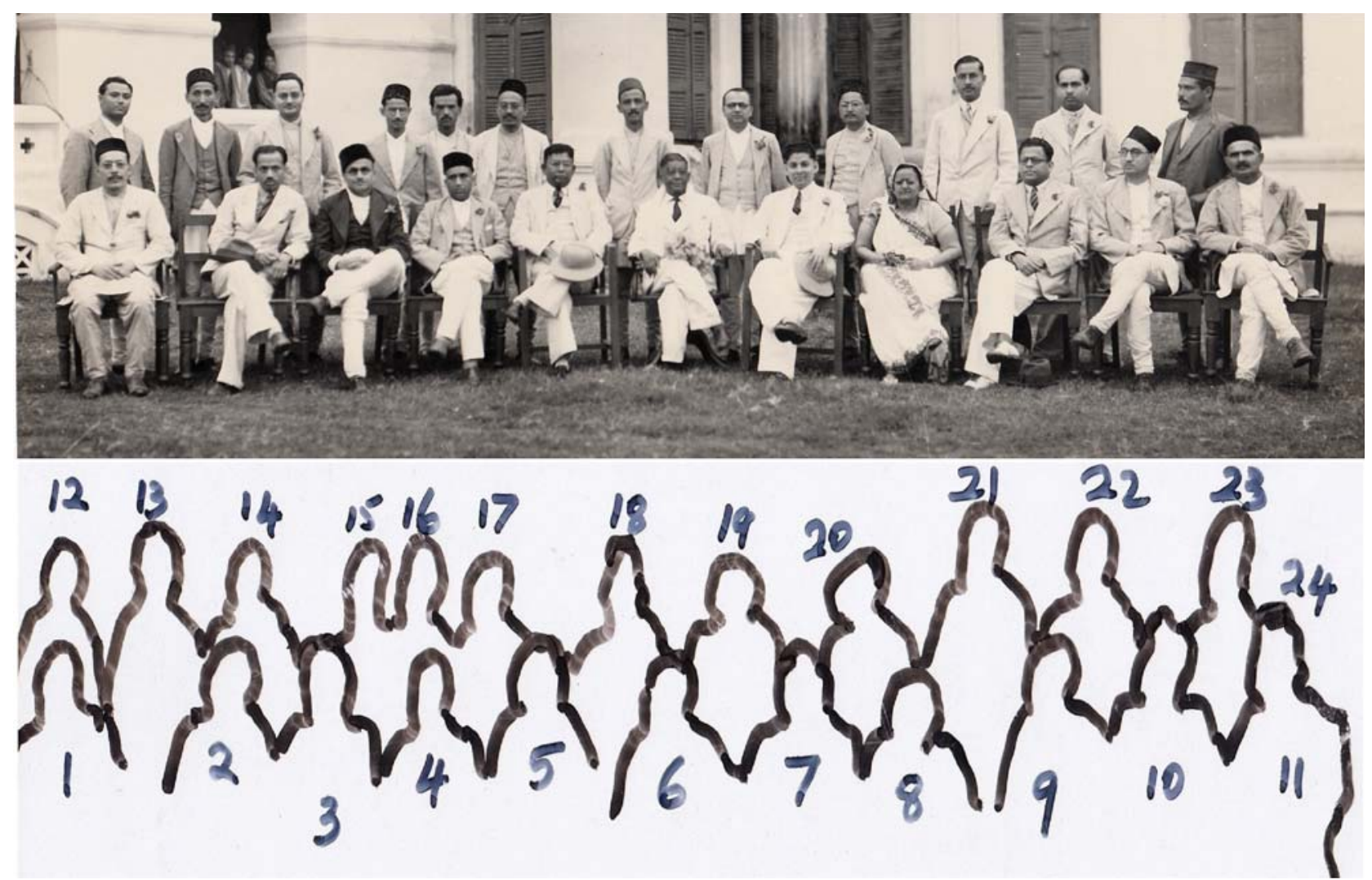

Figure 1: Picture, probably taken over 70 years ago shows the staff of the Bir Hospital of those days.

Key to photograph: 1. Dr. Indra Man Baidya 2. Dr. Sushil K Haldar 3. ? Dr. Pinaki P Acharya 6. Dr. Suresh Dass Gupta 7. Dr. Debrata Dasgupta 8. Dr. Dhana Seth 10. Dr. Prakash B Basnyat 11. Dr. Devi P Upadhaya 13. Compounder Hira Nanda Vaidya 14. Dr. Jit Singh Malla 17.Dr.Yagya Man Baidya 19. Dr. Siddhimani A Dixit 21.? Sushil Majumdar

The bed number of Bir Hospital was increased from 30 to 60 during the tenure of Juddha Shumsher JB Rana. There was the Bir Male Hospital with male compounders and dressers 5 . Bir Female Hospital had a lady doctor as Medical Superintendent and female ward attendants. The PM was also keen that the medical personnel working in Nepal should be well trained for we find a letter dated $28^{\text {th }}$ October to the British authorities stating:

"In order that the benefit of the latest improved surgical techniques might be made available to the general public here, we are thinking of sending to Calcutta, Doctor Suresh Chandra Dass Gupta LMS to learn at the premier institution at that place. The doctor is the Chief Medical Officer of the Bir Hospital, Kathmandu, and is also known to the British Legation Surgeon as a good hand in surgery."

As from 1934 the Civil Medical School which was essentially a training school for basic grades of health workers viz. compounders and dressers was based at Bir Hospital $^{6}$. Dr. Prakash B Basnyat later became the first
Nepali to be appointed for surgical duties. His sudden demise in 1956 (Shrawan 2013 BS) was a great setback for surgery. Dr. Devi Prasad Upadhyay had been giving anaesthesia at that time but he later handed over these duties to Dr. Bhabani Bhakta Singh who had anaesthesia training and came back with DA from India in 1956.

Following the end of the Rana rule in Nepal major changes took place in Bir Hospital. When Dr. Siddhimani Dixit became the Director General of Health Services he had offices at the building near the gate which subsequently became the Medical Superintendent's office ${ }^{7}$.

Initially the Bir Hospital compound bisected by the road leading to Mahaboudha had the Civil Medical School, Chandra Sale Dispensary and the Pathology Department on the Northern section. The Bir Male and Bir Female Hospitals and the Radiology Department were on the Southern side. All these were made in a single complex and Dr. Mahendra Prasad became Superintendent of the same in 1957. The two hospitals (male and female) had a 


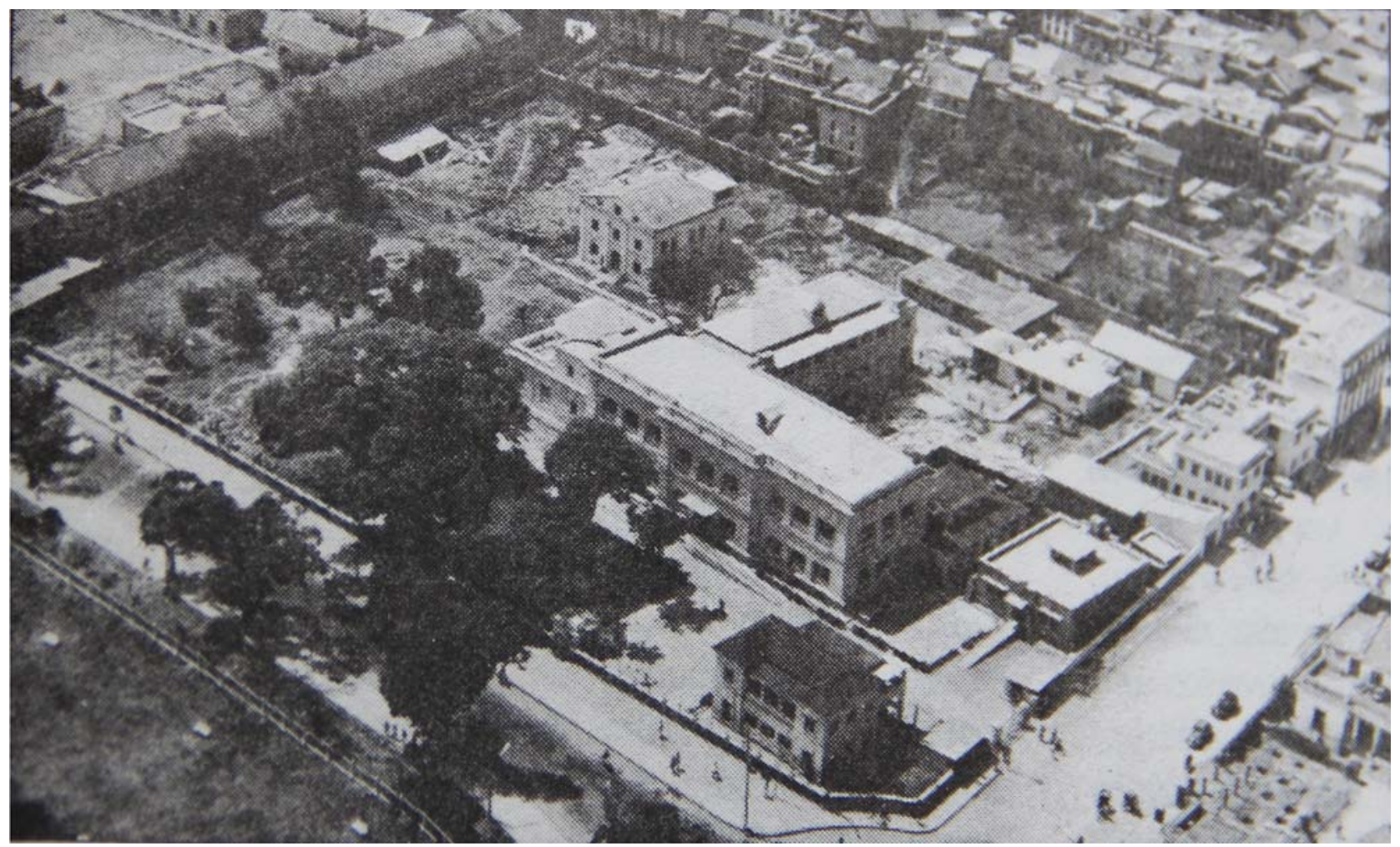

Figure 2: Aerial picture of the Bir Hospital compound showing its different components ${ }^{8}$

hundred beds each ${ }^{8}$. The initial renovation which started in 1965 with the help of USAID, was construction of the Surgical Block, a nurse's residence and the combining of male and female blocks into a single general hospital. This took a couple of years to complete. The Teku Hospital was a unit of Bir Hospital as was also the Kanti Hospital at Maharajgunj. There was talk around this time about starting a medical college with the help of India and a Dr. Bhandarkar, then Director General of Health Services in Maharastra State of India had also come to Nepal in this connection. This did not materialise.

There was a Kumari temple in the Northern section of the Bir Hospital compound but there were not many worshippers there as there was a belief that who so ever performed puja there would be transferred. During the time that I was there, the then Medical Superintendent did one possibly with the wish to be elevated to a higher post ${ }^{7}$ !

When the New Education System Plan was introduced in 1972 the responsibility of conducting medical education became the responsibility of the Institute of Medicine (IoM), one of the components of Tribhuvan University. It trained Basic, Middle and from 1978 when the MBBS course was started, the Higher grades of health personnel. As the loM did not have its own hospital then, the clinical or practical aspects of many programmes, including the MBBS, were all done at Bir Hospital.

New OPD facilities, with help from India, opened in November 1985. The frontage of the building showed Hanuman, the Monkey God carrying Sanjeevani in his upturned right palm.

Following the decision to develop different superspecialities at the Bir Hospital, the ADRA Sydney Hospital Heart Project started there in 1987 as one such and carried out closed heart surgery 9 .

In 1994 when Dr. Ram Baran Yadav was the Minister for Health and Population, a Post Graduate Medical Education Co-ordination Committee was formed with faculty and specialists of Institute of Medicine and Bir Hospital. It was under the aegis of this PGMECC that various programmes of the one year Diploma and three years Degree levels were started.

In 2002, after 114 years of functioning, the Bir Hospital was concurrently made into the National Academy of Medical Sciences and is responsible for PG training such as MD / MS for medical doctors. Courses run in various hospitals in Kathmandu Valley ${ }^{10}$. NAMS has the status of a deemed university. Preference is given to doctors 


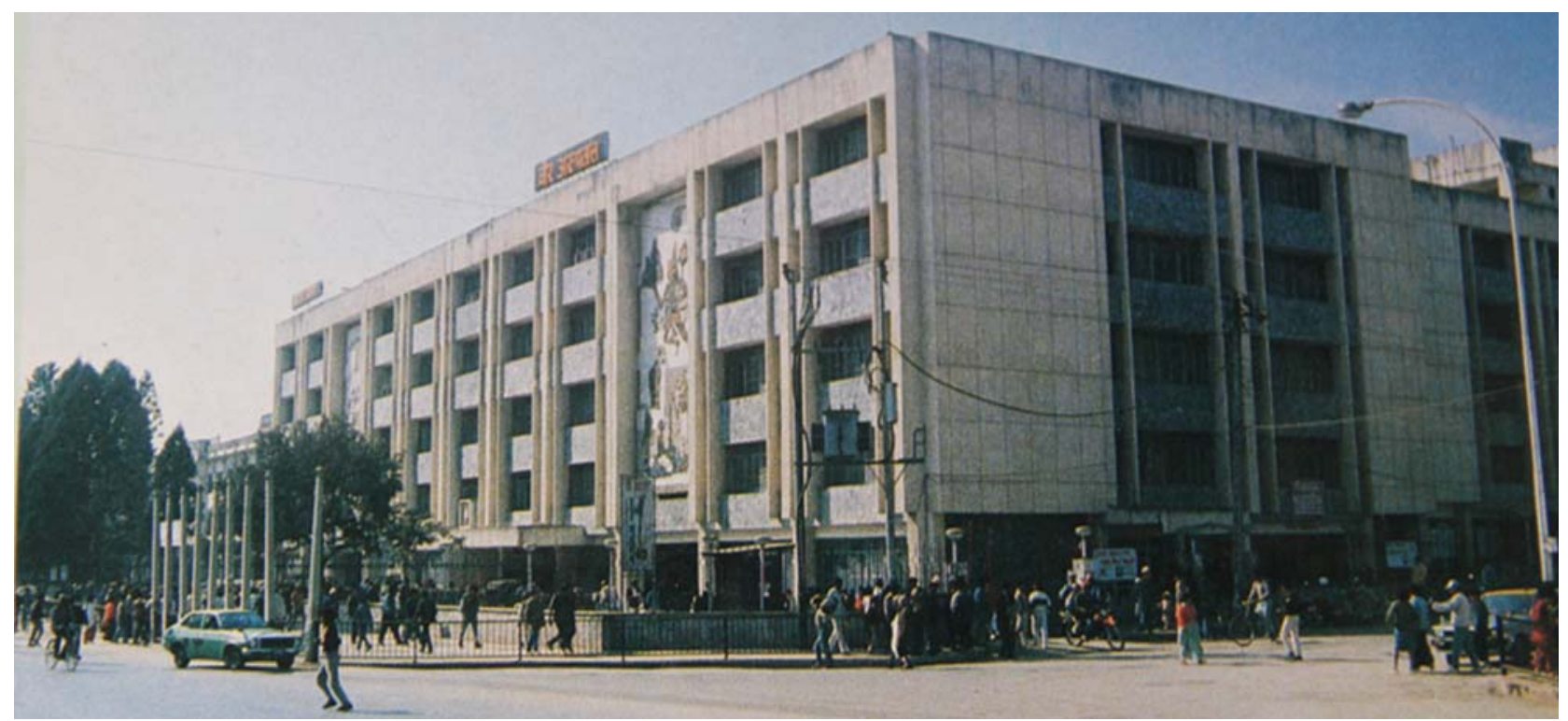

Figure 3: Frontage of the New OPD facilities ${ }^{8}$

in government service and working in far flung areas for admission in the academic courses. The MDS course in some dental specialities is also conducted. Besides these the PCL and BN courses are also done there.

On $7^{\text {th }}$ June 1997 the Indian PM Mr. IK Gujral during the course of his three-day visit unveiled the plaque for the construction of a 200 - bedded Emergency and Trauma Centre to be built with aid of the Indian Government. The construction was started as late as 2006 and the hospital was finished in 2009.

The recent visit of Indian Prime Minister Narendra Modi or NaMo to Nepal to inaugurate the Trauma Centre in the Bir Hospital (NAMS) on $25^{\text {th }}$ November 2014, one day prior to the $18^{\text {th }}$ SAARC Summit is seen by many as a timely effort by him to bring to fruition a project which should have been completed and functioning in the service of the population for some years.

\section{ACKNOWLEDGEMENT}

I would like to acknowledge the help of Dr. Dwarka N Regmi, Dr. Laxman Poudyal and Dr. Moin Shah in trying to identify the people in the staff picture of Bir Hospital that was taken over 70 years ago. Also Dr. Siddharth Dixit, Mr. Nirmal Bista, Ms. Bindu Phuyal and Mr. Kapil Thapa for their help in preparation of same.

\section{REFERENCES}

1. Stiller LF. Nepal: The Growth of a Nation. Human Resources Development Research Center. Kathmandu: Human Resources Development Research Center; 1993.

2. Paudel NN, Dixit H. Bir Hospital of Yesteryears. Bir Hospital Centenary Souvenir; 1989-90.

3. Dixit H. Nepal's Quest for Health. 4th ed. Kathmandu: Educational Publishing House; 2014.

4. Sir Tuker F. Gorkha. The story of the Gurkhas of Nepal. London: Constable and Co; 1957.

5. Malla FB. A Few Lines on Bir Hospital. Bir Hospital Centenary Souvenir, 1989-90. p107-08.
6. Shah M. Reminiscences. $121^{\text {st }}$ Anniversary Souvenir of Bir Hospital; 2010. p91-94.

7. Dixit H. Origin of the Paediatric Species. Bir Hospital Centenary Souvenir; 1989-90.

8. Prasad M. Bir Hospital Reminiscences of a Challenge. Bir Hospital of Yesteryears. Bir Hospital Centenary Souvenir; 1989-90. p86-90.

9. Karki DB. Development of Cardiology in Nepal. Bir Hospital Centenary Souvenir, 1989-90.

10. Sharma VK. Bir Hospital and the Nepal Academy of Medical Sciences (NAMS): Their Relations need to be defined. $120^{\text {th }}$ Anniversary Souvenir of Bir Hospital; 2009. p10-13. 